\title{
PENERAPAN MODEL PEMBELAJARAN BERBASIS MASALAH UNTUK MENINGKATKAN MOTIVASI DAN PRESTASI BELAJAR MATEMATIKA SISWA KELAS VIII B SMP N 7 SINGARAJA
}

\author{
P. N. Periandani, I. N. Gita, Sariyasa \\ Jurusan Matematika, Fakultas Matematika dan IImu Pengetahuan Alam \\ Universitas Pendidikan Ganesha \\ Singaraja, Indonesia \\ e-mail: novi_periandani@yahoo.com, nyoman.gita@undiksha.ac.id, sariyasa@undiksha.ac.id
}

\begin{abstract}
Abstrak
Penelitian ini bertujuan untuk mengetahui: (1) peningkatan motivasi belajar matematika siswa kelas VIII B SMPN 7 Singaraja melalui penerapan model pembelajaran berbasis masalah, (2) peningkatan prestasi belajar matematika siswa kelas VIII B SMPN 7 Singaraja melalui penerapan model pembelajaran berbasis masalah, dan (3) tanggapan siswa kelas VIII B SMPN 7 Singaraja terhadap model pembelajaran berbasis masalah. Penelitian ini merupakan penelitian tindakan kelas yang dilaksanakan dalam tiga siklus dengan subjek penelitian adalah siswa kelas VIII B SMPN 7 Singaraja sebanyak 32 orang siswa. Data motivasi siswa dikumpulkan menggunakan angket motivasi, data prestasi belajar siswa dikumpulkan dengan menggunakan tes prestasi belajar, dan tanggapan siswa dikumpulkan menggunakan angket tanggapan siswa. Data yang telah terkumpul selanjutnya dianalisis secara deskriptif. Hasil penelitian menunjukkan bahwa motivasi dan prestasi belajar matematika siswa mengalami peningkatan dan rata-rata skor tanggapan siswa telah berada dalam katagori positif.

Kata kunci: Model Pembelajaran Berbasis Masalah, Motivasi Belajar Matematika, Prestasi Belajar Matematika

Abstract
This study aims to find out: (1) an increase in mathematics learning motivation of VIII B class students of Singaraja 7 Junior High School through the application of problem-based learning models, (2) improvement of mathematics learning achievement of VIII B class students of Singaraja 7 Junior High School through the application of problem-based learning models, and ( 3 ) responses of students of class VIII B of SMPN 7 Singaraja to problem-based learning models. This research is a classroom action research which is carried out in three cycles with the research subjects being students of class VIII B of SMPN 7 Singaraja as many as 32 students. Student motivation data was collected using motivation questionnaire, student achievement data were collected using learning achievement tests, and student responses were collected using student response questionnaires. The data that has been collected is then analyzed descriptively. The results showed that the motivation and achievement of students' mathematics learning had increased and the average response score of students had been in the positive category.
\end{abstract}

Keywords: Problem Based Learning Model, Mathematics Learning Motivation, Mathematics Learning Achievement

\section{PENDAHULUAN}

Pendidikan Nasional Indonesia bertujuan untuk meningkatkan ketaqwaan kepada Tuhan Yang Maha Esa, meningkatkan kecerdasan dan keterampilan, mempertinggi budi pekerti, memperkuat kepribadiaan dan mempertebal semangat kebangsaan agar dapat menumbuhkan manusia-manusia pembangunan yang dapat membangun dirinya sendiri dan bertanggung jawab atas pembangunan bangsa. Program wajib belajar 12 tahun merupakan salah satu upaya pemerintah untuk meningkatan kualitas pendidikan.

Matematika merupakan salah satu mata pelajaran wajib yang dibelajarkan dalam setiap jenjang pendidikan, mulai dari pendidikan dasar hingga pendidikan tinggi. Banyak siswa yang beranggapan bahwa matematika merupakan mata pelajaran yang sulit untuk dipahami sehingga banyak yang kurang berminat untuk belajar matematika. Hal ini berdampak pada kurangnya prestasi belajar matematika yang dimiliki oleh siswa. Prestasi belajar siswa dapat dikatakan baik apabila siswa tersebut dapat memahami pembelajaran tersebut dengan baik. Untuk melihat prestasi belajar siswa dapat digunakan beberapa indikator, seperti: (1) Ranah Kognitif (pengamatan, ingatan, pemahaman, penerapan, analisis, dan sintesis); (2) Ranah Afektif (penerimaan, sambutan, apresiasi, 
internalisasi, karakterisasi); dan (3) Ranah Psikomotor (keterampilan bergerak dan bertindak, serta kecakapan ekspresi verbal dan nonverbal). Dari ketiga ranah tersebut dapat kita lihat bahwa penting sekali bagi siswa untuk meningkatkan prestasi belajar yang dimilikinya untuk dapat memiliki wawasan yang luas serta terjun di masyarakat.

Guna memperoleh prestasi belajar yang baik dalam kegiatan pembelajaran juga diperlukan motivasi yang tepat agar peserta didik mampu dan mau belajar dengan baik agar target prestasi belajar yang diinginkannya dapat tercapai. Motivasi berperan penting dalam peningkatan prestasi belajar siswa dikarenakan asumsi bahwa semakin kuat motivasi belajar yang dimiliki siswa maka akan semakin rajin pula siswa tersebut belajar dalam memahami setiap materi pembelajaran yang diberikan oleh guru di kelas. Siswa yang memiliki motivasi belajar yang tinggi akan tergerak untuk mencari, menggali dan mengembangkan bakatnya sehingga dalam diri siswa tersebut terdorong untuk belajar dan menemukan pemahamannya sendiri.

Berdasarkan observasi yang peneliti lakukan di kelas VIII B SMP N 7 Singaraja, ditemukan bahwa motivasi dan prestasi belajar yang dimiliki oleh siswa pada kelas tersebut masih jauh dari harapan. Hal tersebut dapat dilihat dari hasil ulangan siswa selama pertengahan semester. Dari hasil ulangan tersebut dapat dilihat bahwa sebagian besar siswa masih belum dapat mencapai nilai kriteria ketuntasan minimal (KKM) yang telah ditentukan oleh sekolah yaitu 60 . Berdasarkan informasi tersebut, dapat diperhatikan bahwa prestasi belajar matematika masih belum sesuai dengan yang diharapkan, sebab masih banyaknya siswa yang belum memenuhi KKM. Hal ini juga didukung oleh hasil observasi awal pada proses pembelajaran yang dilakukan di kelas VIII B SMP N 7 Singaraja yang dilakukan selama 2,5 bulan. Didapati beberapa permasalahan yang diperkirakan merupakan faktor kurang maksimalnya prestasi belajar siswa khususnya dalam mata pelajaran matematika yang diduga bahwa motivasi belajar yang dimiliki siswa masih lemah. Hal ini dilihat dari sikap-sikap yang ditunjukkan oleh siswa pada saat kegiatan pembelajaran berlangsung, dimana masih banyak siswa yang belum aktif dalam mengikuti pembelajaran yang dilaksanakan oleh guru, dalam menngerjakan soal yang diberikan oleh guru masih banyak siswa yang tidak langsung mengerjakan soal tersebut secara mandiri melainkan menunggu jawaban dari temannya dan/atau menunggu jawaban yang diberikan oleh guru. Dari kurangnya motivasi yang dimiliki oleh siswa sehingga berdampak pada kurangnya kemampuan siswa dalam menyelesaikan soal yang diberikan yang menyebabkan banyaknya siswa yang belum dapat mencapai KKM.

Dalam upaya mengatasi permasalahanpermasalahan di kelas VIII $\quad$ B SMP $\quad \mathrm{N} 7$ Singaraja ini, dapat dilakukan dengan meningkatkan peranan guru. Guru harus dilatih untuk menguasai keterampilan-keterampilan dasar dalam pembelajaran misalnya 1) keterampilan bertanya, 2) keterampilan memberi penguatan, 3) keterampilan mengadakan variasi, 4) keterampilan menjelaskan, 5) keterampilan membuka dan menutup pelajaran, 6) keterampilan membimbing diskusi, 7) keterampilan mengelola kelas. Dengan keterampilanketerampilan ini guru dapat meningkatkan aktivitas belajar siswa di kelas. Selain dengan meningkatkan keterampilan guru, guru juga harus menyesuaikan model pembelajaran yang sesuai dengan karakteristik siswa kelas VIII-B di SMP N 7 Singaraja, seperti model pembelajaran berbasis masalah.

Model pembelajaran berbasis masalah dapat mengarahkan siswa untuk mencari tahu sendiri secara berkelompok mengenai pemecahan dari masalah yang diberikan oleh guru, dimana hal tersebut tentu memerlukan pengetahuan-pengetahuan yang telah dimiliki oleh siswa dan mengaitkannya dengan permasalahan yang diberikan sehingga diperoleh pemecahan dari permasalahan yang diberikan tersebut. Selain itu, pembelajaran akan semakin bermakna apabila permasalahan-permasalahan yang diberikan di dalam kelas juga ditemui oleh siswa di lingkungan luar sekolah yang pada akhirnya mereka mampu mengaplikasikan solusi permasalahan yang telah dibahas di dalam kelas ke dalam kehidupan nyata. Siswa mampu mengintegrasikan pengetahuan dan keterampilannya secara bersamaan. Dengan pembelajaran yang berbasis masalah, maka pengetahuan siswa perlu dikombinasikan dengan keterampilan mereka dalam pemecahan masalah. Siswa mampu membangun kemampuannya secara mandiri dalam proses pembelajaran. Hal ini dapat terjadi karena PBM memberikan kesempatan siswanya untuk mencari pemecahan masalah secara mandiri, sehingga siswa harus menjelajahi terlebih dahulu apa saja yang mereka ketahui yang kemudian dapat mereka kembangkan sendiri karena adanya permasalahan baru yang berkaitan dengan halhal yang diketahuinya. Membentuk karakter siswa yang aktif, kreatif, dan kritis. Karena pembelajaran yang berbasis masalah dan 
menuntut kemandirian siswa, maka siswa akan cenderung lebih aktif mencari tahu, kreatif menemukan solusi, dan kritis dalam memilah informasi yang diperoleh. Menumbuhkembangkan inisiatif dan motivasi siswa dalam belajar. Hal ini disebabkan karena masalah yang diberikan tidak langsung diberitahukan penyelesaiannya oleh pendidik, sehingga siswa harus berinisiatif untuk mencari tahu solusinya. Selain itu, dengan masalah yang bersifat keseharian yang sudah familiar di lingkungan siswa maka siswa akan termotivasi untuk menuangkan pemikirannya dalam pemecahan masalah tersebut.

Siswa mampu mengatasi permasalahan yang dialami ketika belajar secara individu, sebab dalam PBM siswa dibagi ke dalam beberapa kelompok sehingga dapat berdiskusi antara siswa satu dengan yang lainnya. Selain itu dengan menerapkan model pembelajaran berbasis masalah dalam kegiatan pembelajaran dapat mengembangkan pemikiran kritis, menumbuhkan inisiatif siswa dalam bekerja, memotivasi siswa untuk belajar, membantu siswa belajar untuk mentransfer pengetahuan baru, dan dapat mengembangkan hubungan interpersonal siswa dalam bekerja kelompok.

Berdasarkan uraian tersebut, maka peneliti termotivasi untuk melakukan penelitian yang berjudul "Penerapan Model Pembelajaran Berbasis Masalah Untuk Meningkatkan Motivasi Dan Prestasi Belajar Matematika Siswa Kelas Viii B Smp N 7 Singaraja”.

\section{METODE}

Penelitian ini merupakan penelitian tindakan kelas (classroom action research) yang bersifat kolaboratif, yang secara umum bertujuan untuk meningkatkan dan memperbaiki kualitas pembelajaran di kelas VIII B SMPN 7 Singaraja yang bermuara pada meningkatnya motivasi belajar dan prestasi belajar matematika siswa. Tahapan yang dilakukan dalam penelitian

\section{HASIL DAN PEMBAHASAN}

Berdasarkan penelitian yang dilaksanakan, diperoleh peningkatan motivasi tindakan kelas ini yaitu 1) Perencanaan, 2) Pelaksanaan, 3) Pengamatan, dan 4) Refleksi. Keterlibatan peneliti dalam pembelajaran dalam bentuk kolaborasi antara peneliti dan guru matematika di SMPN 7 Singaraja sehingga memungkinkan terjadinya pemahaman dan kesepakatan terhadap suatu masalah yang dihadapi, pengambilan keputusan yang demokratis sehingga melahirkan kesamaan persepsi terhadap tindakan yang dilakukan.

Subjek dalam penelitian ini adalah semua siswa kelas VIII B SMPN 7 Singaraja semester ganjil tahun ajaran 2018/2019 sebanyak 32 orang siswa. Sedangkan objek dalam penelitian ini adalah (1) motivasi belajar matematika siswa kelas VIII B SMPN 7 Singaraja, (2) prestasi belajar matematika siswa kelas VIII B SMPN 7 Singaraja, dan (3) tanggapan siswa terhadap penerapan model pembelajaran berbasis masalah dalam pembelajaran matematika.

Instrumen dalam penelitian ini berupa angket dan tes di mana angket yang digunakan untuk mengumpulkan data mengenai motivasi belajar siswa dan mengenai tanggapan siswa terhadap penerapan model pembelajaran berbasis masalah dalam pembelajaran matematika. Sedangkan tes yang digunakan untuk mengumpulkan data pretasi belajar matematika yang berbentuk soal uraian. Data yang dikumpulkan selanjutnya dianalisis secara deskriptif, yaitu dengan menghitung rata-rata skor motivasi belajar matematika siswa, nilai prestasi belajar matematika siswa ditinjau dari Kriteria Ketuntasan Minimal (KKM) mata pelajaran matematika dan ketuntasan belajar siswa secara klasikal serta rata-rata tanggapan siswa untuk data tanggapan siswa.

Data motivasi belajar matematika siswa dianalisis secara deskriptif berdasarkan rata-rata skor $(\bar{A})$, mean ideal $(M I)$, dan standar deviasi ideal $(S I)$,

belajar matematika siswa secara klasikal seperti terlihat pada Gambar 1. 


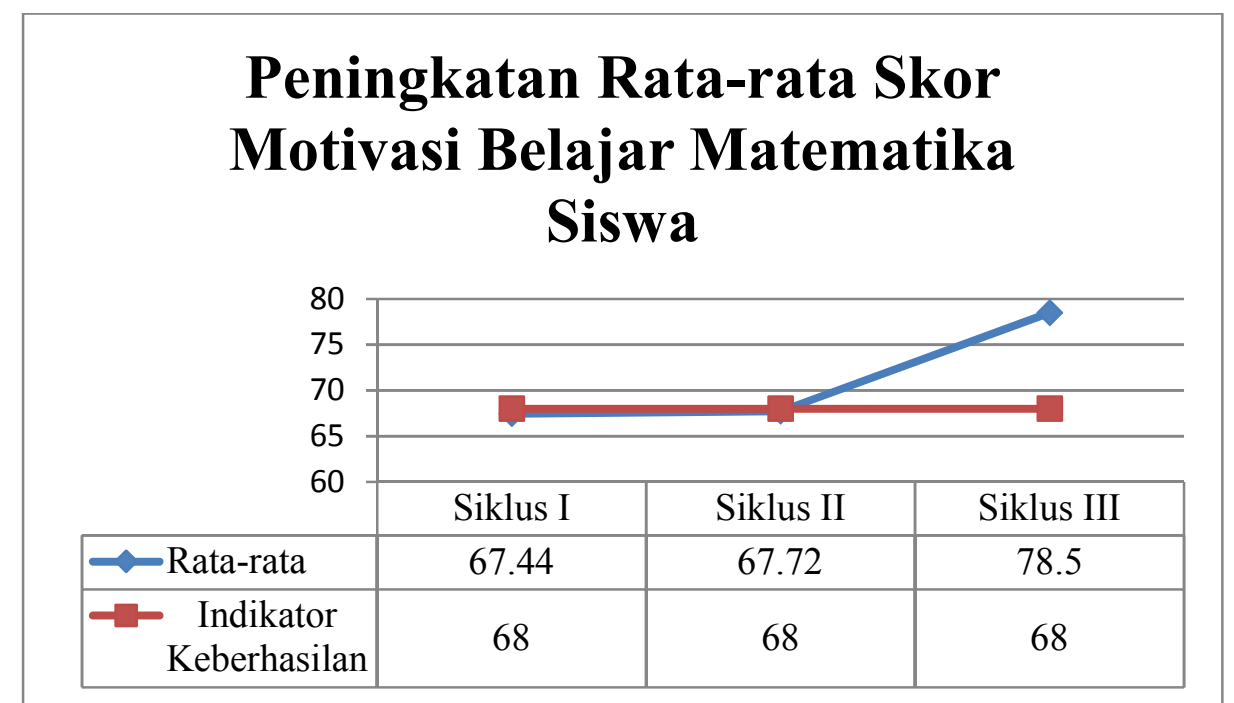

Gambar 1. Grafik Peningkatan Motivasi Belajar Matematika Siswa Secara Klaiskal

Motivasi belajar matematika siswa mengalami pengingkatan dari siklus ke siklus. Dari siklus I ke siklus II rata-rata skor motivasi belajar matematika siswa meningkat sebesar 0,28 dari 67,44 menjadi 67,72. Dari siklus II ke siklus III rata-rata skor motivasi belajar matematika siswa meningkat sebesar 10,78 dari 67,72 menjadi 78,50 . Pada siklus III rata-rata skor motivsi siswa telah mencapai indikator keberhasilan mencapai katagori tinggi.

Peningkatan ketuntasan belajar siswa secara klasikal seperti terlihat pada Gambar 2.

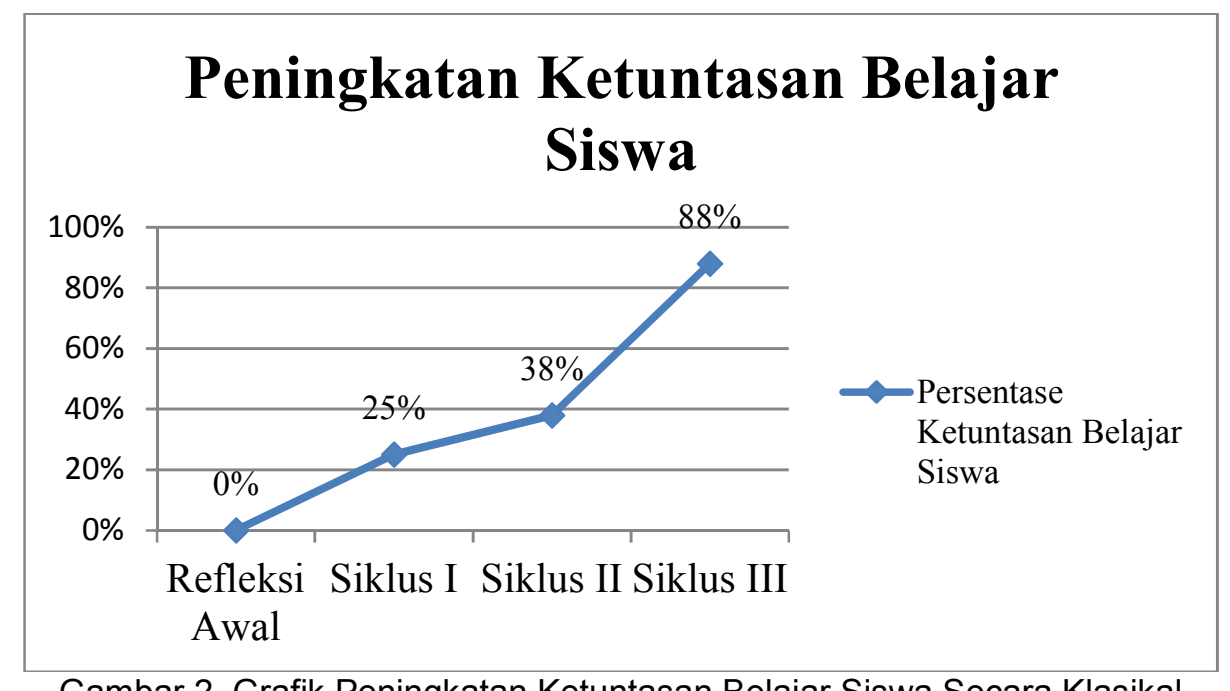

Gambar 2. Grafik Peningkatan Ketuntasan Belajar Siswa Secara Klasikal

Prestasi belajar matematika siswa mengalami peningkatan dari siklus ke siklus. Dari siklus I ke siklus II peningkatan yang terjadi sebesar $13 \%$ yang awalnya sebesar $25 \%$ meningkat menjadi $38 \%$. Dari siklus II ke siklus II meningkat sebesar $50 \%$ yang berawal dari $38 \%$ menjadi $88 \%$.

Pada akhir siklus III siswa mengisi angket untuk mengetahui tanggapan siswa terhadap penerapan model pembelajaran berbasis masalah yang telah dilaksanakan. 


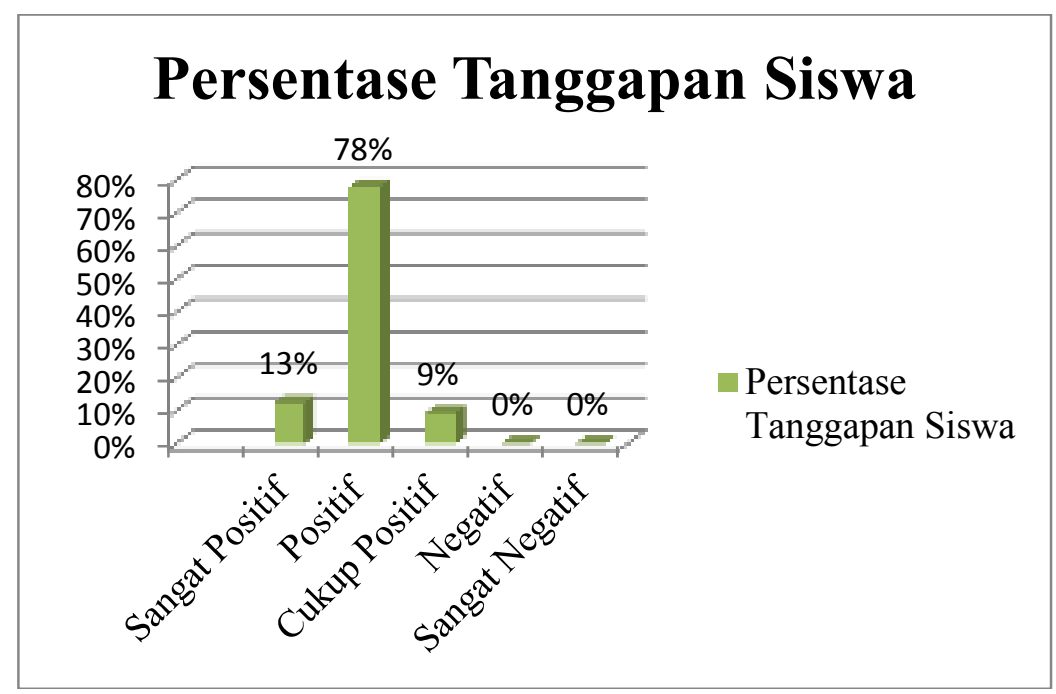

Gambar 3. Grafik Tanggapan Siswa terhadap Penerapan Model Pembelajaran Berbasis Masalah

Berdasarkan hasil penelitian yang telah dilaksanakan selama tiga siklus, terlihat bahwa adanya peningkatan yang terjadi di setiap siklus dan pada akhir penelitian skor rata-rata prestasi belajar Matematikas siswa $\geq$ 60 serta ketuntasan belajar klasikal siswa > $75 \%$. Tanggapan siswa terhadap model pembelajaran berbasis masalah berada dalam katagori positif dengan skor rata-rata 55,28.

Hal tersebut menunjukkan bahwa indikator keberhasilan dari penelitian ini sudah terpenuhi serta penerapan model pembelajaran berbasis masalah dapat mengatasi rendahnya motivasi belajar dan prestasi belajar Matematika siswa kelas VIII B SMPN 7 Singaraja. Tercapainya peningkatan prestasi belajar yang dimiliki siswa secara optimal terjadi pada siklus III, hal ini dibuktikan dengan adanya peningkatan terhadap rata-rata skor motivasi belajar Matematika siswa yang pada awalnya 67,44 menjadi 78,50 pada akhir penelitian. Hal yang sama juga terjadi pada rata-rata nilai prestasi belajar siswa yang pada awalnya 27,66 dengan ketuntasan belajar siswa secara klasikal adalah $0 \%$ menjadi 62,60 dengan ketuntasan belajar secara klasikal adalah $88 \%$ pada siklus III.

Tercapainya indikator keberhasilan pada siklus III disebabkan karena proses pembelajaran pada siklus III ini sudah sesuai dengan skenario yang direncanakan, dimana siswa semakin terbiasa dengan penerapan model Pembelajaran Berbasis Masalah. Dalam kegiatan pembelajaran, guru akan menjelaskan materi pembelajaran dengan menggunakan 5 tahapan dari model pembelajaran berbasis masalah yang diantaranya orientasi siswa pada masalah, mengorganisasikan siswa untuk belajar, membimbing pengalaman individual/kelompok, mengembangkan dan menyajikan hasil karya, serta menganalisis dan mengevaluasi proses pemecahan masalah.

Tahapan-tahapan tersebut akan membantu siswa untuk membangun sendiri pemahamannya terkait materi yang sedang mereka pelajari. Pada tahapan orientasi siswa pada masalah, siswa diberikan masalahmasalah autentik yang berkaitan dengan kehidupan sehari-hari mereka. Dengan diberikannya contoh permasalahan yang berkaitan dengan materi yang sedang dipelajari siswa menjadi lebih mudah untuk membayangkan penyelesaian masalah yang akan mereka lakukan. Hal ini sejalan dengan pendapat Fogarty (dalam Rusman, 2012:243) bahwa pembelajaran berbasis masalah dimulai dengan masalah yang tidak terstruktur, sesuatu yang kacau dimana dari kekacauan tersebut siswa menggunakan berbagai kecerdasannya melalui diskusi dan penelitian untuk menentukan penyelesaian dari masalah tersebut.

Kemudian pada tahap mengorganisasikan siswa untuk belajar, guru membantu siswa untuk mendefinisikan dan mengorganisasikan tugas belajar siswa berdasarkan permasalahan yang telah ditentukan sebelumnya. Memberikan pertanyaan-pertanyaan pancingan untuk membantu siswa memahami permasalahan yang sedang dibahas. Selanjutnya guru mendorong siswa untuk mengumpulkan informasi-informasi yang sesuai, melaksanakan eksperimen untuk mendapatkan penjelasan dan pemecahan masalah.

Setelah mendapatkan informasiinformasi yang sesuai untuk pemecahan masalah tersebut, siswa diarahkan untuk merencanakan dan menyiapkan hasil karya berupa laporan yang nantinya akan mereka presentasikan di depan kelas bersama teman- 
teman kelompoknya. Setelah presentasi dilaksanakan dilanjutkan dengan sesi tanya jawab dengan kelompok lain terkait dengan laporan yang telah mereka sampaikan di depan kelas. Kemudian dengan bantuan guru siswa menganalisis dan mengevaluasi proses berpikir mereka sendiri dan keterampilan penyelidikan yang mereka gunakan.

Dengan menerapkan model Pembelajaran Berbasis Masalah siswa lebih termotivasi, hal ini didukung dari hasil observasi sikap siswa pada setiap pertemuan terhadap model Pembelajaran Berbasis Masalah secara klasikal mengalami peningkatan. Penilaian sikap siswa dapat diamati dengan menggunakan 5 indikator yaitu hadir di kelas tepat waktu, menyelesaikan tugas tepat waktu, aktif mengajukan pendapat atau menjawab pertanyaan guru, aktif dalam kegiatan diskusi, dan mandiri dalam mengerjakan tes yang diberikan oleh guru.

Selain terjadi peningkatan motivasi dan prestasi belajar yang dimiliki siswa, penerapan model pembelajaran berbasis masalah juga mendapat respon yang positif dari siswa. Hal ini diperoleh berdasarkan hasil analisis tanggapan siswa terhadap model pembelajaran berbasis masalah yang telah dilaksanakan dalam proses pembelajaran. Dengan demikian, hasil penelitian ini telah memenuhi semua indikator yang telah ditetapkan. Jadi dapat disimpulkan bahwa penelitian yang telah dilakukan sudah berhasil.

\section{SIMPULAN DAN SARAN}

Berdasarkan hasil analisis dan pembahasan hasil penelitian yang telah diuraikan pada bab sebelumnya, diperoleh simpulan sebagai berikut, (1) motivasi belajar matematika siswa Kelas VIII B SMPN 7 Singaraja dengan penerapan model pembelajaran berbasis masalah mengalami peningkatan. Hal ini disebabkan karena di setiap kegiatan pembelajaran dengan model pembelajaran berbasis masalah mengajak siswa untuk fokus dan memusatkan perhatiannya dalam mengikuti proses pembelajaran. Selain itu, dengan penerapan model pembelajaran berbasis masalah dalam proses pembelajaran membuat siswa lebih antusias dalam belajar karena pada model ini siswa membangun pengetahuannya dengan diskusi kelompok, dan setiap kelompok dibimbing oleh guru serta dengan digunakannya permasalahan-permasalahan yang dekat dengan siswa membuat siswa lebih aktif dalam mengikuti kegiatan pembelajaran. Hal ini tentu didukung dengan rata-rata skor motivasi belajar yang diperoleh siswa selama kegiatan pembelajaran mengalami peningkatan pada setiap siklusnya. Rata-rata skor motivasi belajar siswa pada siklus I adalah 67,44; pada siklus II adalah 67,72; dan pada siklus III adalah 78,50. Dari siklus I ke siklus II terjadi peningkatan sebesar 0,28 ; dan dari siklus II ke siklus III mengalami peningkatan sebesar 10,78. Motivasi belajar Matematika siswa mengalami peningkatan dan berada dalam katagori tinggi, (2) prestasi belajar Matematika siswa Kelas VIII B SMPN 7 Singaraja melalui penerapan model pembelajaran berbasis masalah mengalami peningkatan di setiap siklusnya. Secara umum peningkatan prestasi belajar yang dimiliki siswa Kelas VIII B SMPN 7 Singaraja dari siklus I ke siklus II sebesar 4,67 dengan rata-rata 41,98 pada siklus I menjadi 46,65 pada siklus II. Kemudian dari siklus II ke siklus III mengalami peningkatan sebesar 15,95 dengan rata-rata 46,65 pada siklus II menjadi 62,60 pada siklus III dengan persentase banyaknya siswa yang tuntas sebesar $88 \%$ pada siklus III, serta telah memenuhi indikator keberhasilan yakni minimal memenuhi nilai 60 dan mengalami peningkatan dari siklus ke siklus, dan banyaknya siswa yang tuntas melebihin $75 \%$, dan (3) rata-rata skor tanggapan siswa terhadap penerapan model pembelajaran berbasis masalah yang dikumpulkan melalui angket telah berada dalam katagori positif dengan persentase banyaknya siswa yang memberi tanggapan cukup positif adalah 9\% (3 orang), yang member tanggapan positif adalah $78 \%$ ( 25 orang), dan yang member tanggapan sangat positif adalah $13 \%$ (4 orang). Secara keseluruhan tanggapan siswa terhadap penerapan model pembelajaran berbasis masalah tergolong positif dengan rata-rata skor tanggapan siswa sebesar 55,28, hal ini sesuai dengan indikator keberhasilan dalam penelitian ini.

Berdasarkan hasil penelitian yang diperoleh, adapun saran-saran yang penulis dapat sampaikan yaitu sebagai berikut. (1) Penerapan model pembelajaran berbasis masalah dapat digunakan sebagai salah satu alternatif dalam upaya meningkatkan motivasi dan prestasi belajar Matematika siswa. Untuk itu, kepada guru mata pelajaran Matematika pada umumnya disarankan untuk mencoba menerapkan model pembelajaran berbasis masalah untuk meningkatkan motivasi dan prestasi belajar Matematika siswa. (2) Bagi pembaca yang ingin menerapkan model pembelajaran berbasis masalah diharapkan mencermati kendala-kendala yang peneliti alami ketika pelaksanaan proses pembelajaran, sehingga nantinya akan diperoleh hasil yang lebih baik daripada penelitian yang dilakukan oleh peneliti serta 
dapat melakukan penelitian lebih lanjut dengan menggunakan variasi strategi dan metode pembelajaran yang berada dengan tetap mempertahankan keunggulan-keunggulan dari pembelajaran dengan menggunakan model pembelajaran berbasis masalah ini.

\section{DAFTAR PUSTAKA}

Anggriani, Rian. 2017. Pengaruh Model Pembelajaran Problem Based Learning (PBL) terhadap Kemampuan Pemecahan Masalah dan Motivasi Belajar Siswa pada Materi Lingkaran SMP Kelas VIII. Jurnal Pendidikan Matematika, Volume 01, Nomor 08, halaman 2-3, Tahun 2017. Tersedia pada http://simki.unpkediri.ac.id/mahasisw a/file artikel/2017/a0413c71c9dbe0 2c39be5c0980f17166.pdf

Amiluddin, Risnawati dan S. Sugiman. 2016. Pengaruh Problem Posing dan PBL terhadap Prestasi Belajar, dan Motivasi Belajar Mahasiswa Pendidikan Matematika. Jurnal Riset Pendidikan Matematika, Volume 3, Nomor 1, halaman 100-108, Tahun 2016. Tersedia pada https://journal.uny.ac.id/index.php/jr pm/article/view/7303

Arcana dan Ika Fitri K.S. 2018. Efektivitas Model Pembelajaran Problem Based Learning (PBL) dan Example Non Example terhadap Proses Belajar untuk Siswa Kelas VIII di MTs Negeri 7 Gunungkidul. Jurnal Pendidikan Matematika, Volume 6, Nomor 1, halaman 1-10, Tahun 2018. Tersedia pada

http://jurnal.ustjogia.ac.id/index.php/ union/article/download/1295/pdf

Arikunto, Suharsimi. 2016. "Dasar-Dasar Evaluasi Pendidikan". Jakarta: Bumi Aksara.

Aritonang, K. T. 2008. "Minat dan motivasi dalam meningkatkan hasil belajar siswa. Jurnal Pendidikan Penabur, 7(10), 11-21."

Candiasa, I Made. 2010a. Pengujian Instrumen Penelitian Disertai Aplikasi ITEMAN dan BIGSTEPS. Singaraja: Unit Penerbitan Universitas Pendidikan Ganesha.

,2010b.Statistik Univariat dan Bivariat Disertai Aplikasi SPSS. Singaraja: Unit Penerbitan Universitas Pendidikan Ganesha.

Chairul, Anwar. 2017. Buku Terlengkap TeoriTeori Pendidikan Klasik hingga
Kontemporer Formula dan Penerapannya dalam Pembelajaran. Yogyakarta: IRCiSoD.

Departemen Pendidikan Nasional. 2002. Pendekatan Kontekstual Teaching and Learning. Ditjen DIKDASMEN, Direktorat Pendidikan Lanjutan Pertama. Jakarta: Depdiknas.

Fitriani, Melli. 2017. Pengaruh Model Problem Based Learning terhadap Motivasi Belajar Sistem Koordinasi pada Siswa di SMA Negeri 2 Bantaeng. Jurnal Biotek, Volume 5, Nomor 1, halaman 228-239, Tahun 2017. Tersedia pada http://journal.uinalauddin.ac.id/index.php/biotek/articl e/download/3460/3253

Nurdin, Syafruddin dan Adriantoni. 2016. Kurikulum dan Pembelajaran. Jakarta: PT Raja Grafindo Persada.

Pradnyana, P.B. $2013 . \quad$ Pengaruh Pembelajaran Berbasis Masalah terhadap Motivasi Belajar dan Prestasi Belajar Matematika Siswa Kelas IV SD. e-Journal Program Pascasarjana Universitas Pendidikan Ganesha Jurusan Pendidikan Dasar, Volume 3, Tahun 2013. Tersedia pada https://media.neliti.com/media/public ations/119603-ID-pengaruhpembelajaran-berbasis-masalaht.pdf

Rusman. 2012. Model-Model Pembelajaran Mengembangkan Profesionalisme Guru. Jakarta: PT Raja Grafindo Persada.

Santoso, Bagus, dkk. 2016. Penerapan Model Problem Based Learning dalam Peningkatan Pembelajaran Matematika tentang Soal Cerita Pecahan pada Siswa Kelas V SD N 1 Kedungwinangun Tahun Ajaran 2015/2016. Jurnal Pendidikan Guru Sekolah Dasar, Volume 4, Nomor 6.1, halaman 713-718, Tahun 2016. Tersedia pada http://jurnal.fkip.uns.ac.id/index.php/ pgsdkebumen/article/view/8510

Setiyawan, Hery. 2017. Pembelajaran Matematika Model PBL (Problem Based Learning) pada Mata Pelajaran Matematika Materi Luas Bidang pada Siswa Kelas III SD. Jurnal Pendidikan Guru Sekolah Dasar, Volume XIX, Nomor 1, halaman 8-17, Tahun 2017. Tersedia pada

http://fbs.uwks.ac.id/myfiles/files/IN OVASI, $\% 20$ Volume $\% 20$ XIX, $\% 20$ No 
mor\%201,\%20Januari\%202017/2.\% 20Artikel $\% 20$ Hery $\% 20$ Edit $\% 20$ hal $\%$ 208\%20-\%2018.pdf

Sulamiasih. 2015. Pengaruh Pembelajaran Berbasis Masalah terhadap Motivasi Belajar dan Prestasi Belajar Matematika Siswa Kelas VI SD Gugus II Kecamatan Tejakula Tahun Pelajaran 2014/2015. e-Journal Program Pascasarjana Universitas Pendidikan Ganesha Program Studi Pendidikan Dasar, Volume 5, Tahun 2015. Tersedia pada https://media.neliti.com/media/public ations/124840-ID-pengaruhpembelajaran-berbasis-masalaht.pdf

Wanda Ratnasari, Ika. 2017. Hubungan Minat Belajar terhadap Prestasi Belajar Matematika. Jurnal PSIKOBORNEO, Volume 5, Nomor 2, halaman 400405, Tahun 2017. Tersedia pada http://ejournal.psikologi.fisipunmul.ac.id/site/wpcontent/uploads/2017/08/JURNAL\% 20IKA\%20WANDA\%20R\%20(0831-17-11-12-41).pdf

Widya Satya. 2013. Revisi Taksonomi Pembelajaran Benyamin S. Bloom. Jurnal FKIP Universitas Kristen Satya Wacana, Volume 29, Nomor 1, halaman 30-39, Tahun 2013. Tersedia pada http://www.researchgate.net/profil// Putu Darmawan/publication/315348 938 REVISI TAKSONOMI PEMBE LAJARAN BENYAMIN S BLOOM/li nks/596052d1a6fdccc9b1c4bd32/RE VISI-TAKSONOMIPEMBELAJARAN-BENYAMIN-SBLOOM.pdf 